NBSIR 88-3821

\title{
The ABC's of Certification Activities in the United States
}

Maureen A. Breitenberg

U.S. DEPARTMENT OF COMMERCE

National Bureau of Standards

Office of Standards Code and Information

Office of the Associate Director for Industry and Standards

Gaithersburg, MD 20899

\section{FHE COPY \\ DO NOT REMOVE}

July 1988
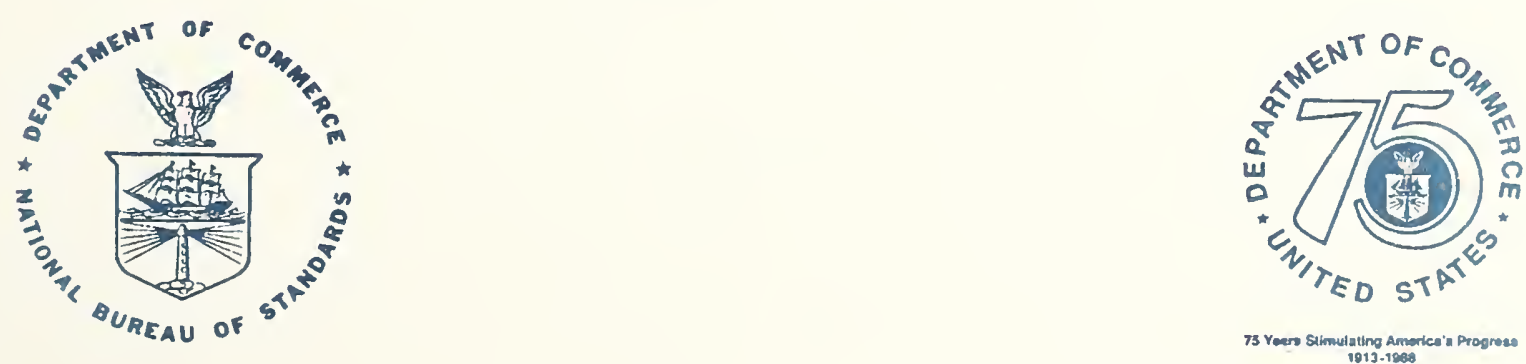

U.S. DEPARTMENT OF COMMERCE

NATIONAL BUREAU OF STANDARDS 

NBSIR 88-3821

\section{THE ABC'S OF CERTIFICATION} ACTIVITIES IN THE UNITED STATES

Maureen A. Breitenberg

U.S. DEPARTMENT OF COMMERCE

National Bureau of Standards

Office of Standards Code and Information

Office of the Associate Director for Industry and Standards

Gaithersburg, MD 20899

July 1988

U.S. DEPARTMENT OF COMMERCE, C. William Verity, Secretary NATIONAL BUREAU OF STANDARDS, Ernest Ambler, Director 



\section{Foreword}

The Office of Standards code and Information periodically develops and publishes standards-related documents as a service to producers and users of standards and certification programs, both in govermment and in the private sector. This report is a sequel to NBSIR 87-3576, The ABC's of Standards-Related Activities in the United States, and is designed to provide the reader with additional information on one standards-related activity - certification. This document is a further introduction to certification for those not fully familiar with this complex field. We hope that this material will be informative and will serve to stimulate wider understanding of the purpose and nature of certification. In addition, the interested reader may wish to take advantage of other available publications and services provided by this office, some of which are described in the appendix.

Questions concerning this document and any comments or suggestions to improve its format or content will be welcome.

Donald R. Mackay

Manager, Office of Standards code and Information

National Bureau of Standards, Administration Bldg., Rm. A-629 Gaithersburg, MD 20899 


\section{Acknowledgements}

I would like to thank Foster Wilson, Charlie Heyer (the Marley Corp.), Jack Wyatt (DOD), Hank Collins (UL), and many others for their careful review of and comments on this document.

Maureen A. Breitenberg

Office of Standards code and Information 
Abstract

This report, a sequel to NBSIR 87-3576, The ABC's of Standards-Related Activities in the United States, provides a further introduction to certification for a reader who is not entirely familiar with this topic. It highlights some of the more important aspects of this field, furnishes the reader with information necessary to make informed purchases, and serves as background for using available documents and services.

Key Words: certificates of conformity; certification; certification marks; conformance testing; inspection; product listing; quality assurance; standardization; standards; testing 



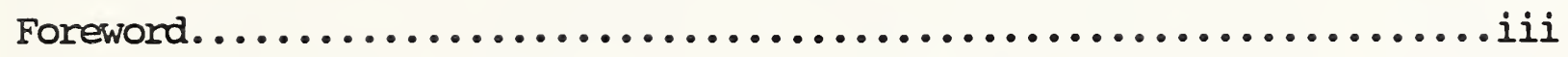

Acknowledgements..................................... iv

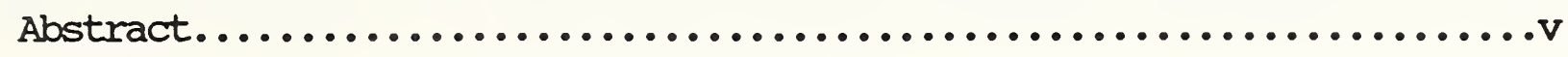

Introduction. $\ldots \ldots \ldots \ldots \ldots \ldots \ldots \ldots \ldots \ldots \ldots \ldots \ldots \ldots \ldots \ldots \ldots \ldots$

Historical Notes....................................

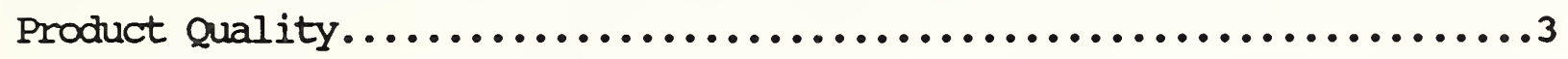

Self-Certification...................................

Third-Party Certification.............................

Third-Party Certification Programs in the United States............5

Federal Govermment Certification Programs in the United States........8

State Certification Programs in the United States................8

International and Regional Certification Programs................9

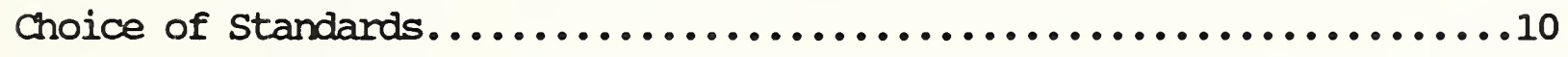

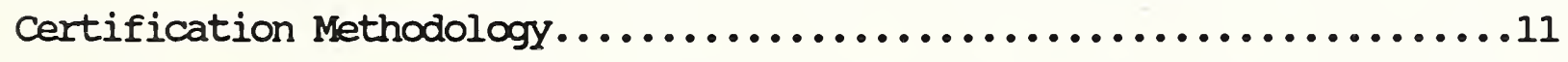

Certificates or Marks of Conformity (Certification Marks) ............12

Potential Problems with Certification Programs..................13

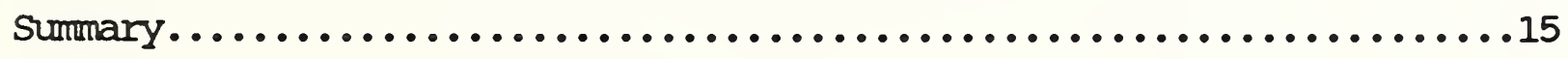

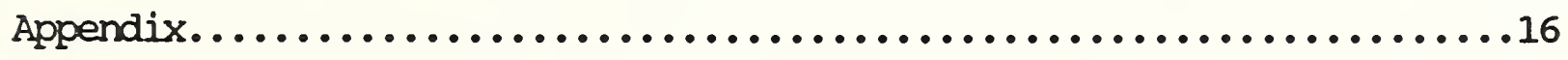

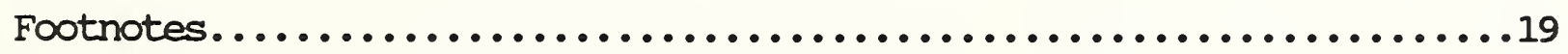





\section{INIRODUCIION}

We live in a perpetually changing world in which technological innovations keep pushing the boundaries of our knowledge. Yet in order to survive, there is a need to regulate - to standardize aspects of our surroundings. Nowhere is this more true than in the marketplace. A state-of-the-art computer is of no benefit without compatible software. Nor does one want to purchase a technologically superior new appliance only to find that its plug does not fit the outlet; or, worse yet, appears to fit, but in fact increases the potential for fire or electrical shock.

Some characteristics of products need to be standardized, and certification programs are a vital link between standards for such products and the products themselves. Certification programs provide a means of assuring that a product has the characteristics or meets the requirements contained in a standard.

One definition of a certification program or scheme is "the procedure by which written assurance is given that a product or service conforms to a standard or specification," $1 /$ but almost as many definitions for a certification program exist as there are organizations attempting to define it. In addition, some organizations use other terms to refer to the process, such as product listing, product evaluation, product requlation, product approval, or the publication of research reports.

Product certification schemes range from the simple to the complex. There are many private organizations, as well as federal and state agencies in the United States, which certify products ranging from electrical cords to meat products. In addition, many certification programs are operated at local government levels. Consumers see evidence of the extensiveness of certification-related activities when they note the Underwriters Laboratories (UL) mark on such products as electric coffee pots and fire extinguishers, the U.S. Department of Agriculture (USDA) mark on poultry and other agricultural products, and the International Wool Secretariat's Woolmark or Woolmarkblend on wool and wool blend textile goods. These are only a few of the many certification marks which appear on products consumers purchase.

The impact of certification programs on trade in both domestic and international markets has become increasingly prominent. The international General Agreement on Tariffs and Trade (GATT) has as one of its major components the Agreement on Technical Barriers to Trade (usually referred to as the Standards code). The framers of the Standards code, including the United States, recognized that activities such as certification programs can expedite or seriously hinder the free flow of goods in international commerce. The code established, for the first time, procedural requirements for certification schemes to avoid the establishment of unnecessary obstacles to trade. The code also ensures that nondiscriminatory access to certification programs will be provided to foreign suppliers. A fundamental principle of the code is the proviso that national or regional certification schemes are to grant access to foreign suppliers in signatory countries under conditions no less favorable than those granted to domestic suppliers. 2f The Trade Agreements Act of 1979, which implemented the Standards code in the United States, enacted similar guidelines within the United 
States to discourage certification schemes that might create unnecessary obstacles to trade.

Ideally, however, a properly conducted certification program benefits, not hinders, the free flow of goods into the marketplace. certification verifies that a particular product meets a given level of quality or safety, providing the user with explicit or implicit information about the characteristics and/or performance of the product. Certification can also increase a buryer's confidence in a product and furmish useful product information. *

Because certification schemes have a significant impact on the marketplace, it is important to have some familiarity with certification terminology and to understand why different types of certification programs provide users with varying amounts of information and degrees of confidence in the resultant certification. This paper is intended to be an introduction to some of the more vital aspects of product certification. It will also discuss some of the benefits and problems associated with certification. Interested readers are encouraged to increase their knowledge of the field by taking advantage of other available publications and services described in the paper, footnotes and appendix.

\section{HISTORICAL NOTFS}

An inscribed stone of the 4th Century BC, found in Eleusis, Greece in 1893, cited a decree regarding the manufacture of bronze fittings for the erection of the columns of a new stoa (portico) which became the Philonion stoa. The bronze specified was copper/tin in a ratio of 11 parts copper to 1 part tin. Professor Varoufakis in his book, Materials Testing in Classical Greece, Technical Specifications of the 4th century BC, $3 /$ argued that the discovery of such a specification implies the existence of some type of check or verification. Professor Varoufakis tested the possibility that this check could have been conducted based on color differences between polished specimens of bronze differing in tin content. He noted a distinct color difference between two specimens when the tin content differed by only 2\%. A similar process for identifying and differentiating gold alloys was already in use in ancient Greece. These may have been two of the earliest forms of certification - metals of unknown content certified as to their composition on the basis of inspections for color.

One of the most ingenious and lasting forms of certification was coinage. When lumps of gold or other precious metal became units of value and weight (the two being indistinguishable) they were marked with an official seal, ultimately becoming certified ingots or what are today known as coins. This did not, however, stop early attempts to circumvent such certifications - chiseling bits of metal from the ingots or coins. In fact, the English language retains

* Under 16 CFR Part 13, misrepresentations of product quality are regarded by the Federal Trade commission as prohibited trade practices. Certification programs provide some assurance that claims made regarding a product's conformance to a particular standard are in fact valid. 
the term "chiseler" as a memorial to the men who figured out difficult-to-detect methods for chiseling metal from certified ingots and coins. 4/

From 1890 to 1900, when the use of gas for domestic cooking and heating began to gain widespread popularity, many new gas appliances were developed and sold. Early records indicate that some thought was given to establishing a gas appliance testing laboratory as early as 1903. The Baltimore investigation, conducted by the National Bureau of standards in 1923, analyzed accidents resulting from the use of domestic gas appliances and flexible gas tubing. The City of Ios Angeles started a similar laboratory and field study in 1924. Both investigations pointed to the need for a certification program for gas appliances. In 1925, the American Gas Association established a laboratory to test and certify gas appliances. The first certified gas heaters and ranges appeared on the market in 1926.

Just 50 years ago, U.S. drug manufacturers could produce and sell drugs without testing them on either animals or humans and without any kind of govermmental approval. Govermmental action could only be taken against drugs which were misbranded or adulterated. In 1937, physicians in Tulsa, Oklahoma reported to the American Medical Association (AMA) the deaths of six patients from a liquified version of the then wonder drug sulfa. Ultimately this drug killed 107 people, mostly children, before doctors realized what was happening and the drug was recalled. This tragedy led to the enactment of the 1938 Food, Drug and Cosmetic Act, which requires that drugs be tested and approved by the Food and Drug Administration before marketing.

Roofing systems are composed of a deck, its cover, insulation, vapor barriers, adhesives, and fasteners. These systems are required to withstand many stresses and hazards. Three materials are used in roof decks - concrete, steel and wood. It was initially believed that fire spread under a deck was a problem for wood construction only. This was one reason the steel deck was rapidly adopted after its introduction during the post World war II years. The 1953 Livonia Michigan fire proved this assumption wrong when fire spread rapidly under a steel deck. Subsequent testing showed that, although the deck itself was not combustible, the adhesive, vapor barrier and insulation used frequently were. Once these materials are heated, they produce gases which, if they can't escape through the roof's covering, are forced through the joints of the deck, where they can ignite and spread along the underside. 5/ This discovery demonstrated the nasd for the certification of not only individual roofing procucts, but of trial roof construction, for fire spread and heat release.

From such early beginnings, the certification industry has grown both in size and complexity.

\section{PRODUCT QUALTTY}

The quality of any product depends on two major elements:

o The design and formulation of the product; and

o The care and consistency of the manufacturing process.

The design and formulation of the product can generally be evaluated against 
specific criteria by physically testing a prototype (or preproduction model) or by reviewing the product's design specifications. Prototype models, which are not necessarily identical to the actual production line output, indicate how a product coming off the assembly line might perform. While successful prototype testing does not necessarily ensure that the production model will perform as expected, such tests are helpful in achieving some assurance of adequate product safety or quality.

The manufacturing process depends on many variables, such as quality of the components or materials, equipment, equipment calibration and maintenance, the training and experience of production and supervisory personnel, the level of "workmanship," and sometimes the envirommental conditions (temperature, humidity, level of dust particles) in the area where the product is produced. The process manufacturers use to control these variables to produce a product of consistent quality or which meets defined specifications is called a quality control or quality assurance (0.A.) system. Fundamental to W. Edwards Deming's approach to management is that "quality comes not from inspection, but from improvement of the production process." $6 /$ Improvements made to the design of the product and the quality of the manufacturing process have the greatest impact on product quality. "Inspection to improve quality is too late, ineffective, costly." I/

The International Organization for Standardization (ISO) has published a series of five International Standards (ISO 9000, 9001, 9002, 9003, and 9004) on the subject of quality assurance which, together with the terminology and definitions contained in ISO Standard 8402, provide a practical and generally applicable set of principles for Q.A. systems. ISO 9000 provides guidance on the selection of the specific quality management program most likely to be appropriate for a manufacturer's operations. ISO 9001,9002 and 9003 describe three distinct quality assurance models of varying stringency, and ISO 9004 examines each of the quality system elements (cross-referenced in ISO 9000) in greater detail. The ISO 9000 series provides excellent guidance and information on basic requirements for quality management in manufacturing industries. The Iso series can also be used for general guidance in service industries.

There is also a growing trend regarding the implementation of quality assurance registration (sometimes misnamed "quality assurance certification"), which may or may not be independent of any certification program. These registrations involve the assessment and periodic audit of the effectiveness of a manufacturer's Q.A. system. A manufacturer can register his Q.A. system with an organization which conducts a quality assurance registration program without participating in a product certification program. The ISO 9000 series has been used as the basis for the development of many such programs internationally.

\section{SETL-CERTITFICATTON}

Self-certification is the process by which a manufacturer or supplier declares that his product meets one or more standards based on: (1) his confidence in his quality control system, or (2) the results of testing or inspection he undertakes or authorizes others to undertake on his behalf. In other parts of the world, this process is also known as a manufacturer's declaration of conformance. The 
manufacturer's capability, integrity, and reputation determine the degree of confidence that can be placed in self-certification.

In the United States, the criteria and procedures reconmended for a selfcertification program are established in American National Standards Institute (ANSI) Standard Z-34.2-1987, "American National Standard for CertificationSelf-Certification by Producer or supplier." Such procedures include the requirement that self-certification be based on conformance with all requirements of a standard unless full disclosure is made of any limitations of the certification. There are also requirements for the adequate use and maintenance of test equipment, an effective quality control system, fully-trained staff, written certification procedures, and adequate record keeping.

One of the most familiar certification programs in the United States involves the identification of the weight of motor oils by the manufacturer of conformance to the Society of Automotive Engineers (SAE) standards. Consumers will recognize such weight designations as SAE 10W-40W or 10W-30W on the motor oils they buy. These SAE designations are placed on the motor oils by the manufacturer based on testing and quality control mechanisms. This is primarily a self-certification program, though SAE does audit manufacturers' self-certifications to ensure that SAE standards are not being misused.

\section{THURD-PARTY CERTIFICATION}

Third-party certification, on the other hand, is "a form of certification in which the producer's claim of conformity is validated, as part of a third-party certification program, by a technically and otherwise competent body other than one controlled by the producer or buyer." 8/ The sponsor of the third-party program (the certifier) may be responsible for collecting the required data, generating test results or conducting inspections, in addition to reviewing the results of such activities and making a final determination on the product's conformance or lack of conformance. Or the certifier may delegate all or part of the data collection and review activities to another party or parties. The degree of confidence that can be placed in third-party certification programs varies greatly depending on (1) the number and types of testing/inspection methods used within the program to assure product conformance, (2) the adequacy of the manufacturer's quality control system, and (3) the competence of the body which conducts the testing and/or inspection and evaluates the test results.

Reconmended criteria and procedures for third-party certification programs in the United States are established in ANSI Standard Z-34.1-1987, "American National Standards for Certification - Third-Party Certification Program."

\section{THIRD-PARIY CBRITIFICATION PROGRAYS IN THE United States}

Private third-party certification programs in the United States are operated by many different types of organizations including:

- Professional or technical societies, such as the American Dental Association (ADA) ; 
- Trade associations, such as the Association of Home Appliance Manufacturers (AHAM) ;

- Independent testing/inspection organizations, such as Underwriters Laboratories (UL), Factory Mutual Engineering and Research (FM), EIL Testing Laboratories, and the MET Electrical Testing Company;

- Organizations oriented toward consumers, industrial buyers, or users of the product or service, such as Good Housekeeping magazine, which offers a consumer protection program for products it approves;

- Organizations composed of producers, testing laboratories, and others concerned with the well-being of an industrial group and/or its customers, such as the Solar Rating and Certification Corp. (SRCC), a nomprofit organization founded in 1980 to certify performance and rate solar energy equipment;

- Organizations comprised of govermment officials involved in the regulation of an industry, such as the Building officials and code Administrators International (BOCA), the International conference of Building officials (ICBO), the Southern Building Code Congress International (SBCCI), and the International Association of Plumbing and Mechanical officials (IAPMD); and

- Other miscellaneous organizations, such as a ship classification society.

One of the oldest certification programs has been operated since 1870 by the American Bureau of Shipping (ABS), a ship classification society. It is concerned with the design, construction and periodic survey of merchant ships and other marine structures. ABS certifications cover over 14,900 vessels and 1,000,000 cargo containers. Other certified products include: mobile offshore drilling and production units, fixed offshore structures, work boats, cranes, yachts, cargo handling engines, and related machinery and materials.

Another well established industry trade association certification program is that of the American Gas Association (AGA), operated since 1925. Over 260 manufacturers participate in AGA's program for gas appliances and accessories. AGA currently certifies a wide range of products including gas-fired central furnaces, gas cooking appliances and even gas-fired toilets. Products are tested in AGA facilities and requirements for certification include: a review of the construction and performance information for the product, factory and quality control inspections and annual product testing/inspections. Additional documentation may also be required. AGA publishes an annual directory of certified appliances and accessories.

More recently established appliance certification programs for room air conditioners, refrigerator-freezers, dehumidifiers, and humidifiers are operated by the Association of Home Appliance Manufacturers (AHAM). The Air-conditioning and Refrigeration Institute (ARI) certifies appliances ranging from air conditioning equipment to water coolers and solar collectors.

A program familiar to many consumers is that of the American Dental Association (ADA), a professional society which operates a program for certifying dental 
materials, instruments, and equipment. The ADA certification program uses ADA standards and requires the submittal of a detailed application describing the product's specifications. ADA also requires self-certification by the manufacturer that the product meets the standard. Product samples obtained on the open market are tested by ADA. Upon approval, ADA authorizes the use of the $A D A$ seal of certification. ADA also publishes approved product lists.

Most consumers take for granted the familiar "UL" mark on a variety of products from electrical appliances to fire extinguishers. The Underwriters Iaboratories (UL), an independent testing laboratory founded in 1894, is not only a major standards writer, but also tests products and materials with respect to potential hazards to life or property, listing those items which appear to pose no significant hazards. The Factory Mutual Research Corporation (FM), is another "product listing" organization, similar to UL. It is a non-profit testing and research organization whose purpose is to try to minimize industrial property damage through a number of activities including product approval. FM issues lists of approved products as different as industrial trucks and building materials.

Gardeners might recognize the AARS (All-America Rose Selections) mark on the rose bushes they purchase. Over $40 \%$ of the roses sold in the United States bear the AARS symbol. The AAS (All-America Selections) mark is used in connection with seed for flowers and vegetables.

The work of other major certification organizations, although equally vital, may be less well known outside the testing/inspection community. The National certified Testing Laboratories (NCIL), an independent testing laboratory, certifies many products from paint to insulated glass. The Metallurgical Engineers of Atlanta (MEA) certifies carpet under the Department of Housing and Urban Development (HUD) carpet certification program developed by the Carpet and Rug Institute.

The National Board of Boiler and Pressure Vessel Inspectors (NBBI), an organization composed of chief boiler inspectors in the United States and Canada, certifies boilers and components, water heaters, pressure vessels, nuclear components and installations, and a number of related products for conformance to the American Society of Mechanical Engineers (ASME) codes. The value of certifying these products to ASME codes is recognized internationally.

Several building code organizations, such as the Building officials and code Administrators International (BOCA), the International conference of Building Officials (ICBO), and the Southern Building Code Congress International (SBCCI), engage in certification-related activities. Composed of building, construction, zoning, and inspection officials, these organizations have developed model building codes which have been adopted by hundreds of state and local govermments. The organizations evaluate products and materials and approve them for conformance with the requirements established in their building codes.

In all, over 110 private sector organizations in the United States certify or list different types of products. The broad range of organizations involved in certification reflects the impact of certification on a vast spectrum of 
interests and disciplines. (See NBS SP 703 for more information on these programs).

\section{FEDERAL GOVERTMFNT CERIIIFICATION PROGRAMS IN THE UNITHED STATFS}

Federal govermment certification programs can be classified into several general categories:

- Programs to certify products which directly affect the health or safety of the user or the general public.

- Programs which test products in order to avoid the necessity for retesting at local levels or prior to each procurement.

- Programs to provide a uniform basis for trade by assessing the quality and condition of products offered for sale. $9 /$

Examples of the first type of certification program include the evaluation and approval by the Food and Drug Administration (FDA), U.S. Dept. of Health and Human Services, of new animal and human drugs, medical devices, biologicals, and other products; the certification by the Federal Aviation Administration (FAA), U.S. Dept. of Transportation, of airplanes and major airplane components; and the certification by the Mine Safety and Health Administration (MSHA), Dept. of Labor, of electrical equipment used in mines.

An example of the second type of program is the Dept. of Defense's (DOD) Qualified Products Listing (QPL) Program for parts, materials and components used in military systems. This program reduces retesting prior to each govermment purchase by testing products and placing those approved on appropriate QPL's. An extension of this concept also underlies the DOD Qualified Manufacturing Iists (OML's) Program, in which a manufacturer's process controls and manufacturing capabilities are evaluated and approved for an entire range of products.

An example of the third type of program is the U.S. Dept. of Agriculture (USDA) program to grade and certify meat and meat products (on a voluntary basis) using uniform grading standards for the burying and selling of such products. The USDA also certifies dairy products, fresh and processed fruits, vegetables, nuts and related products. The National Oceanic and Atmospheric Administration (NOAA), U.S. Dept. of Conmerce, likewise inspects and grades processed fish and shellfish at a seafood processor's request.

\section{STATE CERIIFICATION PROGRAMS IN THE UNITHED STATHS}

States administer many certification programs which cover a diversity of products for a variety of reasons. In some cases, states inspect or test products under authority delegated by the federal government. Many states inspect meat and meat products, certifying those that meet standards established by the USDA. These states then authorize the use of the appropriate USDA marks. Many states inspect and issue certificates of conformity for manufactured homes under authority delegated by the U.S. Dept. of Housing and Urban Development (HUD). States may also impose additional state requirements and simultaneously check for conformity to these and federal requirements. 
States also regulate products under their own authority for health and safety reasons, including amusement rides and insulation, depending on each state's perception of the health and safety impact of such products on its population. Products may be inspected and/or tested directly by the states themselves, or indirectly through a requirement that such products be inspected and/or tested and certified by an approved body, such as a nationally recognized laboratory. An example of the latter is the regulation of electrical products by imposing a state requirement that they be tested/inspected and bear the mark of a "nationally recognized testing laboratory." This term is currently interpreted individually by each state, though the occumational safety and Health Administration is in the process of developing criteria to define what constitutes a "nationally recognized laboratory."

States also regulate products of direct or indirect economic importance. Florida and california, for example, inspect products important to their citrus fruit industry. Nebraska, with a considerable agricultural industry, regulates tractors through a testing program at the University of Nebraska and issues certificates of conformity for approved models. California, with its air pollution problem, stringently regulates auto emissions equipment.

States also inspect/test/certify materials, products, systems and services they procure, such as materials for the construction of state roads and bridges. In yet other cases, the states establish standards and leave enforcement (testing, inspection, etc.) to local authorities. This is sometimes true for building and construction materials.

\section{INIERNATIONAL AND REGIONAL CERIIFICATION PROGRAYS}

The objectives of international and regional certification schemes are:

(1) to ensure an objective assessment of product quality;

(2) to increase the efficiency of international or regional economic cooperation through the removal of technical barriers to trade;

(3) to quicken the circulation of products entering international or regional markets;

(4) to eliminate the need for retesting and thus to reduce the testing/ inspection costs incurred; and

(5) to ensure safety, health and enviromental protection.

In some cases, a reciprocal certification scheme may be established whereby a certificate of conformity (or license to label the product with a certification mark) is granted in one participating country and recognized in other participating countries. An example of this type of scheme at the regional level is the European Committee for Electrotechnical Standardization (CENEIEC) HAR Agreement - an agreement on the use of a marking scheme for electrical cables and cords complying with harmonized specifications. Cables and cords that bear the HAR mark or a colored thread marking must be accepted without further testing or certification by the approval organizations of participating countries. 10/ Another regional example is the CENEIEC Electronic components conmittee System (CECC) under which participants must accept certified electronic components produced under this scheme without further testing. 11/ 
In other types of schemes, provision may be made for the test report prepared in one participating country to be accepted in other participating countries for the purpose of obtaining certification or govermment marketing approval. Examples are the programs coordinated by the European Free Trade Association (EFTA) for pressure vessels, ships' equipment, agricultural equipment and tractors, liquid fuel heating equipment, lifting apparatus (such as hoists, elevators, etc.) and gas appliances. 12/

The required test report may have to establish conformity with applicable standard(s) which have been harmonized (made technically identical or equivalent in practice) between the importing and exporting countries or the report may have to show compliance with technical requirements specified by the importing country alone. In the latter case, the requirements of the importing country may differ significantly from the requirements of the exporting country.

\section{CHOICE OF STANDARDS}

The standards chosen for use in certification programs should specify accurate and reproducible methods of testing for the specified characteristics if the certification program is to have any validity. The standards should also be clearly written and be capable of being uniformly interpreted. However, there are many elements to consider when choosing standards for a certification program.

One of the most obvious considerations in selecting standards is the determination of what product characteristics need to be assessed to achieve the objectives of the program. The International organization for standardization (ISO) has stated that standards suitable for product certification ".... should specify all those and only those characteristics and requirements that are necessary to define the properties of the product or its performance;" and that, if this is not possible, then reference should be made to other relevant standards. 13/ Unless the chosen standards do, in fact, adequately specify all product characteristics that need to be assessed, it will not be possible to fully achieve the program's objectives and the program's value may be questionable.

Certification schemes are normally established to indicate that a procuct meets one or more sets of acceptable or minimm requirements. But what is acceptable? What may be acceptable to one buyer may not be acceptable to another. certification programs may choose standards that result in certified products that satisfy a particular group or organization, such as the goverrment, or the program may choose standards expected to satisfy a larger group of buyers or product users. The choice of standards, therefore, may depend on the needs of the parties likely to use the certification.

Standards containing only one set of requirements and which define only one level of product safety or quality are known as "pass-fail" standards. Either the product meets the minimm requirements (it passes and is certified) or it does not (it fails). Little or no attempt is made to convey information about the relative safety or quality of one certified product compared to other certified products. Unless other methods can be found to convey such information, a manufacturer may be less motivated to produce products which exceed the minimm requirements specified in the standard. 
Certifiers may therefore wish to provide information on the quality or safety of one certified product relative to other certified products. This may be accomplished by selecting standards which define several levels of product safety or quality and by including a grading scheme in the certification program. Information can be conveyed by stating the expected life of the product, such as the expected number of miles that tires are supposed to travel, or the versatility of the product, such as portable fire extinguishers rated for several specified types of fires, or the efficiency of the product, such as the energy efficiency rating for appliances. Buyers, assured of at least a minimm level of safety and/or quality, can then choose among certified products based on any additional level of quality or safety that they desire, other product characteristics or features, and/or product price.

A choice must also be made as to whether the establishment of conformity should be based on an assessment of a product's performance or its design. A performance standard, for example, may require that a pipe be able to withstand a given level of pressure with no limitations on materials used or on how the product is to be designed. A design standard, on the other hand, might specify the material to be used, its thickness, and other design characteristics to ensure that the resulting pipe could withstand a given level of pressure. All standards are to some extent restrictive, but design standards limit flexibility in product engineering and innovation to a greater extent than do performance standards. For example, if the material specified for the pipe was plastic, then a metal pipe would fail the certification process even if it could withstand greater pressure than the plastic pipe. Performance standards, however, tend to be difficult to develop and difficult to use in assessing product compliance. problems may arise in establishing reliable test methods for assessing conformity, thus potentially increasing certification costs.

The choice of standards for a certification program has a significant impact on the validity of the program, the value of the product information conveyed by the certification, and the program's cost.

\section{CERTIFICATION METHODOLOGY}

Third-party certification programs differ greatly from one another, and the degree of confidence in the resultant certification depends on the type of program and its comprehensiveness (the number and types of test/inspection methods used within the program to assess conformity).

The methods used in third-party certification programs can be classified as follows:

- Type-testing/Initial Inspection - This method attempts to determine if the mamufacturer's design specifications can produce a product that conforms to a particular standard. Products from a preproduction run are inspected and/or tested, but this method provides no information on whether products from an actual production run also consistently meet the specification. 
- Surveillance of the Manufacturing Process - Assessment of a manufacturer's materials, production and control processes can, at relatively low cost, provide assurance that the manufacturer's quality control procedures are adequate.

- Audit-Testing - In this procedure, test samples are selected at random from the marketplace. Extensive testing is usually required to provide adequate assurance that products meet the referenced standard.

- Field Investigations - Alleged failures of products during actual use are investigated to determine the cause of failure and to suggest appropriate corrective action.

- Batch-testing - A sample of products is selected from a production batch and tested for conformance to the standard. If the sampling procecture and the sarmle size are adequate, batch-testing may be used to predict, with a specified degree of confidence, that all products in that batch conform to the standard. It does not, however, ensure that an untested product in the batch will meet the standard nor does it furnish information on the quality of products produced in earlier or subsequent batches. Batch testing is used in many certification programs for building products.

- 100 Percent Testing - In this method, each individual product is tested to determine if it meets the designated standard. If the testing procedures are adequate, the procedure provides the highest possible level of assurance that the product conforms to a particular standard. It is also usually the most expensive method and can be applied only where the test has no adverse effect on the product. 14/

Many certification programs rely on two or more of these methods for their approval process. The choice of methods depends on the needs of both the buryer and the seller and on the nature of the procuct. The chosen methods can greatly affect both the cost of the program and the level of confidence that can be ascribed to it.

ANSI and ISO have each developed criteria to evaluate certification programs. ANSI has also developed a program to accredit certification schemes which meet its criteria. 15/ One of the criticisms of self-certification, namely that the mamufacturer does not have a third party checking the cormetence and integrity of his results, fails to recognize that thind party certification programs which are not accredited also do not have anyone looking over their shoulder to ensure the quality of their programs. 16/

\section{CERIIIFICATES OR MARKS OF CONFORMIIIY (CFRIIFICATION MARKS)}

A mark of conformity or certification mark is defined as "a sign or symbol owned or controlled by the certification body that is used exclusively by the thirdparty certification program to identify prockucts or services as being certified and is registered as a certification mark [when used in the United States] with the U.S. Patent Office under the Trade Marks Act of 1946." 17/

A certificate of conformity, on the other hand is "A tag, label, nameplate, or document of specified form and contents, affixed or otherwise directly associated 
with a product or service on delivery to the buyer, attesting that the product or service is in conformity with the referenced standards or specifications." 18/

Certification marks and certificates of conformity should be used to indicate that all essential characteristics of the product have been assessed. In cases where only one or several aspects of the product have been evaluated, such as flammability or electrical safety, this information should be conveyed in some manner to the buyyer lest the mark mislead the buyer into placing more reliance on the certification than is justified. To the extent possible, the symbols used in connection with the certification mark should be capable of being interpreted without further definition. The marks or accompanying information should also indicate the identity of the certification body and any relationship that the body may have to the manufacturer.

In addition, the certificate of conformity should contain information on: (1) the lot, batch or other production information to allow traceability to the production source and time of production; (2) the date when the certificate was issued; and (3) the officer of the company responsible for its issuance.

Labeling included with the prockuct should identify the producer, and contain information on the product's name, type or model number and all instructions necessary for the correct and safe use and maintenance of the product.

\section{POTENILAI, PROBTENS WITH CERTIIFICATION PROGRAYS}

While certification programs benefit both the seller and buyer of a certified product, certification programs also have the potential for misleading users and for other abuses. Some of the more significant potential problems in certification programs include:

1. The Use of Inspection/Testing/Certification as a Substitute for Improving the Quality of the Product and the Manufacturing Process.

As Deming has pointed out, quality must be designed into the procuct and assured through an effective and efficient manufacturing process. Inspection, testing, and certification will provide information on whether the desired end result has been achieved, but usually too late in the manufacturing process to improve the quality of the inspected/tested products.

\section{Lack of Appropriate Standards on Which to Base the Certification.}

Standards may not exist which cover all essential characteristics of the product necessary to ensure a given level of quality or safety, or the standards may exist but not be readily available.

\section{Technical Deficiencies in the Standards.}

The introduction of new technology and new products may be inhibited particularly when design (rather than performance) standards are used for certification and there is no provision to handle products which fall outside the scope of the standard. Standards may also contain specifications that are unnecessary and not 
based on well documented research or information, or the specifications may be inadequate to ensure an acceptable level of product quality or safety.

\section{Lack of Valid Reproducible Test Methods.}

Test methods may not adequately measure essential characteristics or specifications included in the standard with reproducible results, or the cost of testing might be prohibitive. Sample size requirements may not be sufficient to ensure adequate representation of the entire production line. Adequate test equipment, maintenance and calibration equipment may be difficult to procure or unavailable. Laboratory conditions (temperature, humidity, level of dust particles, etc.) may also negatively influence the outcome of the test results.

5. Lack of Technical and Financial Competency on the Part of the Certifier, Testing or Inspection Organization.

The certifier, laboratory, and/or inspection agency may lack the necessary technical competence and resources to properly use and maintain the test equipment, to conduct the required inspection/testing, and to evaluate the results. The organizations may not have developed adequate written documentation on the certification requirements and procedures or may not have kept adequate records on the testing/inspection results. The certifier or testing/inspection organization might have ties to the manufacturer or other biases which might compromise the integrity of the results.

\section{Public Misperception Regarding Iegal Responsibility for a Certified Product or Service}

Despite public perception and assumptions that certification implies legal responsibility for the quality and/or safety of the product or service certified by a third party, most certifiers are not willing to accept such responsibility. Responsibility for this liability generally rests with the manufacturer.

\section{Lack of an Adequate Appeals System.}

Disagreements may occasionally arise among parties participating in a certification program. Provision should be made within a program for an impartial appeals mechanism to handle disagreements that cannot otherwise be resolved. Procedural requirements should be in writing with minimal limitations on the timing of appeals, and on who may file.

\section{Lack of Knowledge on the Part of Users of the Certification Scheme.}

Buryers who rely on a certification scheme and who are not adequately informed as to the purpose, scope, and technical limitations of the resultant certification may be misled as to the value and degree of confidence that can be placed on the mark or certificate of conformity.

\section{Lack of Adequate Follow Up and Enforcement.}

Without adequate means to ensure that any misuse of the certification mark or certificate of conformity is dealt with efficiently and effectively, the mark's 
integrity may be compromised. Successors to the early "chiselers" continue to try to circumvent certification requirements. Steps must be taken to ensure that only authorized products bear the mark and that certified products that are subsequently found to be hazardous or to have quality defects are either recalled from the marketplace or have their marks or certificates of conformity removed.

\section{Incompatibilities among National Certification Schemes.}

When national certification schemes for the same product or group of products differ significantly, the result can be the noed for extensive retesting at considerable expense in terms of both time and money. The potential barriers to trade which can result from differences in national certification programs have been discussed earlier in this paper.

\section{SUMMARY}

Certification programs are communication tools designed to rechuce the cast of exchanging information between buyer and seller. The quality of the information conveyed depends on both the impartiality and competence of the certifier and the adequacy and appropriateness of the standards against which the product is evaluated. Certification may result in widespread buryer deception if the performance characteristics or test methods contained in a standard are insufficient to assure adequate product performance or if the buyer is misinformed as to the extent to which product characteristics have been evaluated.

The United States has some of the most intricate certification schemes in the world. Federal, state, and local goverment certification activities impact on almost every aspect of life in the United States. It is therefore important for all buryers to understand the certification process and what particular marks of conformity mean to enable them to assess the value of certification information to make intelligent choices. 


\author{
Information Available from \\ Office of Standards code and Information (OSCI) \\ National Bureaul of Standards \\ Administration Building, Room A-629 \\ Gaithersbung, MD 20899 \\ (301) $975-4040$
}

- The ABC'S of Standards-Related Activities in the United States (NBSIR 87-3576)

This report provides an introduction to voluntary standardization, product certification and laboratory accreditation for a reader who is not fully familiar with these topics. It highlights some of the more important aspects of these fields; furnishes the reader with both historical and current information on these topics; describes the importance and impact of the development and use of standards; and serves as background for using available documents and services.

- Functions of the NBS Associate Director for Industry and Standards (NBSIR 873623)

This article describes the standardization and metrological activities of the office of the Associate Director for Industry and Standards (ADIS) and its five coordinated programs: the Office of Standards code and Information, the office of Standards Management, the office of Weights and Measures, the Office of Research and Technology Applications and the National Voluntary Iaboratory Accreditation Program.

- Directory of International and Regional organizations conducting Standards-Related Activities (NBS SP 649)

Directory contains information on 272 international and regional organizations which conduct standardization, certification, laboratory accreditation, or other standards-related activities. Volume describes their work in these areas, as well as the scope of each organization, national affiliations of members, U.S. participants, restrictions on membership, and the availability of any standards in English.

- Standards Activities of Organizations in the United States (NBS SP 681)

The directory summarizes the standardization activities of more than 750 organizations in the United States, including federal and state agencies and approximately 420 private sector groups that develop standards. It also contains listings of state procurement offices, sources of standards documents and information, a subject index and related listings that cover acronyms and initials, defunct bodies and organizations with name changes.

- Private Sector Product Certification Programs in the United States (NBS SP 703)

This directory presents information from 109 private sector organizations in the United States which engage in product certification activities. Entries describe the type and purpose of each organization, the nature of the activity, product certified, standards used, certification requirements, availability and cost of services, and other relevant details. 
- Federal Government Certification Programs (NBS SP 739)

This directory presents information on U.S. Goverment certification programs for products and services. Entries describe the soope and nature of each certification program, testing and inspection practices, standards used, methods of identification and enforcement, reciprocal recognition or acceptance of certification, and other relevant details.

- KWIC Index (Computer output Microform (COM) produced)

The KWIC Index contains the titles of more than 25,000 U.S. voluntary product and engineering standards. A standard can be located by means of any significant or key word in the title. Key words are arranged alphabetically. A standard with five key words, for example, would therefore be listed in five different places. To purchase microfiche copies of the Index, contact the National Technical Information Service, 5285 port Royal Road, Springfield, VA 22161; (703) 487-4600.

0 tbt news

This newsletter provides information on govermment programs and available services established in support of the GATT Agreement on Technical Barriers to Trade (Standards code). tbt news reports on the latest notifications of proposed foreign regulations; bilateral consultations with major U.S. trade partners; programs of interest to U.S. exporters; and availability of standards and certification information. Subscription is free upon request.

\section{- Technical Barriers to Trade}

This booklet explains the basic rules of the international Agreement on Technical Barriers to Trade negotiated curing the Tokyo Round of the Multilateral Trade Negotiations (MIN), and describes Title IV of the U.S. Trade Agreements Act of 1979 which implements the United States' obligations under the Agreement. The Agreement, popularly known as the standards code, was designed to eliminate the use of standards and certification schemes as barriers to trade. The booklet describes the functions of the Departments of commerce and Agriculture, the Office of the U.S. Trade Representative, and the State Department in carrying out the U.S.'s responsibilities.

- "GATT Standards Code Activities"

This brochure gives a brief description of NBS' activities in support of the Standards code. These activities include operating the U.S. GATT inquiry point for information on standards and certification programs and notifying the GATT Secretariat of proposed U.S. regulations; assisting U.S. industry with trade-related standards problems; responding to inquiries on foreign and U.S. proposed regulations; and preparing reports on the standard code.

- Report to the United States Congress on the Agreement on Technical Barriers to Trade - "Standards code"

This 2nd triennial report describes the programs and activities established to implement the Standards code in the United States by the four responsible U.S. govermment agencies: Office of the U.S. Trade Representative; Dept. of Conmerce (National Bureau of Standards, Intermational Trade Administration); Dept. of Agriculture and State Department. 
- Free handout material on ADIS, NCSCI and GATI activities, and standards-related information such as: goverrment sources of specifications and standards, use of the KWIC index, foreign and international standards bodies, U.S. standards organizations, state purchasing offices, NCSCI fact sheet and its certification rules activity, and ADIS publications list (bibliography).

In addition to general inquiry services, the following assistance is also available:

- GATT Hotline

A telephone hotline provides current information received from the GATT Secretariat in Geneva, Switzerland, on proposed foreign regulations which may significantly affect trade. The recorded message is updated weekly and gives the product, country, closing date for comments (if any) and Technical Barriers to Trade (TBT) notification number. The hotline number is (301) 975-4041 (not toll-free).

- Assistance to U.S. and foreion exporters - Current regulations and certification information for the manufacture of products in the U.S. for export are obtained from foreign countries. To aid foreign exporters, NCSCI provides directory information to state offices prepared to respond to queries concerning conditions to be met by goods for sale in their state, as well as standaids and certification information for export to the U.S. 
1 American National Standards Institute (ANSI), Z-34.1-1987: American National Standards for Certification - Third-Party Certification Program, American National Standards Institute, New York, New York, p. A-7.

2) International Trade Administration (ITA), The Tokyo Round Agreements: Technical Barriers to Trade - Volume 4, Dept. of Commerce, Washington, D.C., September 1981, p. 4 .

3/ G. J. Varoufakis, Materials Testing in Classical Greece, Technical Specifications of the 4th Century BC, Hellenic organization for Standardization, Athens, Greece, 1983.

4/ John Perry, Story of Standards, Funk \& Wagnalls Company, New York, New York, 1955, p. 28.

5f "Roofing Products Face Stringent Tests Before Receiving FM Approval: An Interview with William F. Maroni, Manager, Building Materials Section," 1988 Factory Mutual Approved Products News, 2nd Quarter 1988, pp. 10-11.

6/ W. Edwards Deming, out of the Crisis, Massachusetts Institute of Technology, Cambridge, MA, 1986, p. 29.

7/ W. Edwards Deming, out of the Crisis, Massachusetts Institute of Technology, Cambridge, MA, 1986, p. 28.

8/ ANSI, p. A-7.

9/ Robert B. Toth, NBS SP 714 - Federal Govermment Certification Programs for Products and Services, U.S. National Bureau of Standards, Washington, D.C., 1986, p. 1 .

10/ Technical Help to Exporters (THE), International Certification and Approval Schemes, British Standards Institution, Milton Keynes, England, 1987, pp. 12-15.

11/ Ibid., pp. 16-19.

12/ Ibid., pp. 32-35.

13/ International Organization for Standardization (ISO), Guide 7, "Requirements for Standards suitable for Product Certification," ISO, Geneva, Switzerland, 1982 , p. 1.

14/ Douglas B. Thomas, NVIAP Glossary of Terms for Laboratory Accreditation, Product Certification and Standardization, U.S. National Bureau of Standards, Washington, D.C. 1980, pg. 4.

15) ANSI, Policy and Procedures \& Mamual of operations for Accreditation of Certification Program, ANSI, New York, NY, 1976. 
16/ Foster C. Wilson, Certification in Operation, unpublished, December 1986, pg. 3.

17) ANSI, Z-34.1, p. A-7.

18) ANSI, Z-34.1, p. A-8. 
NBS. 114A (REV. 2-8C)

U.S. DEPT. OF COMM.

BIBLIOGRAPHIC DATA

SHEET (See instructions)
1. PUBLICATION OR REPORT NO.

NBSIR 88-3821
2. Performing Organ. Report Nof 3. Publication Date

July 1988

4. TITLE AND SUBTITLE

The $A B C$ 's of Certification Activities in the United States

5. $\operatorname{AUTHOR}(S)$

Maureen A. Breitenberg

6. PERFORMING ORGANIZATION (If joint or other than NBS, see instructions)

7. ContracVGrant No.

$\mathrm{N} / \mathrm{A}$

NATIONAL BUREAU OF STANDARDS

8. Type of Report \& Period Covered

U.S. DEPARTMENT OF COMMERCE

Final

GAITHERSBURG, MD 20899

9. SPONSORING ORGANIZATION NAME AND COMPLETE ADDRESS (Street, City, State, ZIP)

Same as in No. 6 Above.

10. SUPPLEMENTARY NOTES

[ Document describes a computer program; SF-185, FIPS Software Summary, is attached.

11. ABSTRACT (A 200-word or less factual summary of most significant information. If document includes a significant bibliography or literature survey, mention it here)

This report, a sequel to NBSIR 87-3576, The ABC's of Standardization Activities in the United States, provides a further introduction to certification for a reader who is not entirely familiar with this topic. It highlights some of the more important aspects of this field, furnishes the reader with information necessary to make informed purchases, and serves as background for using available documents and services.

12. KEY WORDS (Six to twelve entries; alphabetical order; capitalize only proper names; and separate key words by semicolons) certificates of conformity; certification; certification marks; conformance testing; inspection; product listing; quality assurance; standardization; standards; testing

13. AVAILABILITY

XX Unlimited

$\square$ For Official Distribution. Do Not Release to NTIS

$\square$ Order From Superintendent of Documents, U.S. Government Printing Office, Washington, D.C. 20402.

X Order From National Technical Information Service (NTIS), Springfield, VA. 2216I
14. NO. OF PRINTED PAGES

28

15. Price

$\$ 11.95$ 




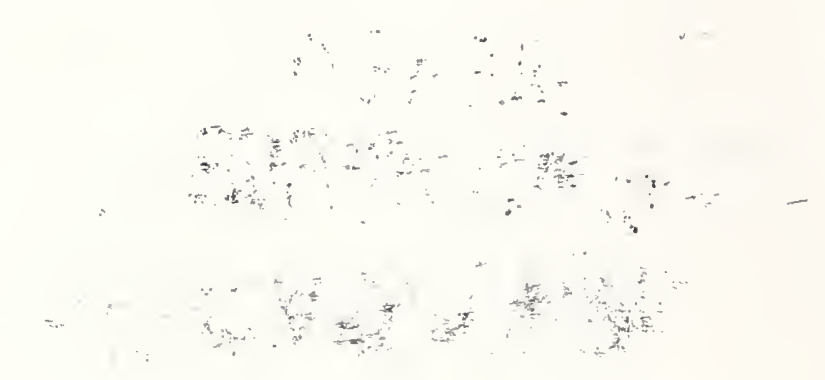

